\title{
GAZNELI ORDUSUNDA GÖREV ALAN HINTLILER
}

\section{ERDOĞAN MERÇIL}

Gazneli Devleti kurulduktan hemen sonra hükümdarlar Hindistan seferlerine başlamış ve bu kıtadaki insan kaynağından askerî yönde de faydalanmışlardır. Bu konuda önemli bilgiler Prof. Dr. C.E. Bosworth tarafindan "Ghaznevid Military Organisation" başlıklı makalesinde ve Gazneliler ile ilgili iki kitabında açıklamıștır ${ }^{1}$. Ancak Prof. Bosworth tarafından verilen bilgilerde bazı eksiklikler göze çarpmaktadır. Biz bu makalemizde hem eksikleri tamamlamaya, hem de bu konudaki olaylanı hatırlatmaya çalışacağız. Eksiklikleri tamamlarken en önemli kaynağımız ise, Beyhakî'nin Tarih-i Beyhakî adlı eseri olacaktır. Bu eser elimize eksik ulaşmasaydı, muhakkak ki, konumuz hakkında daha etraflı bilgi sahibi olacaktık.

Gazneliler'den önceki Müslüman devletler, söz gelişí Büveyhîler, Saffarîler ve Samanîler ordularında acaba Hintliler'den faydalandılar mı? Mafizullâh Kabir'2in eserinde Büveyhîler' in Hintli askerlerden faydalandığı hususunda bir bilgi bulunmuyor. Öte yandan Abbas-ı Pervîz (Deyâlime ve Gazneviyân, hș. 1336, s. 148), Adud ed-Devle zamanında (936-983) Büveyhî ordusunda Hintliler' in bulunduğunu zikrediyor. Türkiye'de Samanîler ile ilgili olarak son zamanlarda yapılan bir doktora çalıșmasında da bu devletin ordularında Hintliler'in yer aldığı konusunda bir bilgi yoktur ${ }^{3}$. Ancak Saffarîler'in Ya'kub b. Leys döneminden (867-879) itibaren ordularında Hintli askerler kullandıkları anlaşılıyor. Bu askerler 919-923 yılları arasında Saffarî Devleti'nde karışıklıkların yaşandığı dönemde önemli rol oynamışlardır'4 Fakat Gazneli Devleti'nde görev yapan Hintliler' in orduda daha aktif rol oy-

${ }^{1}$ Bk. "Ghaznevid Military Organisation", Der Islam, Berlin 1961, Cilt 36, s.37-77; Aynı mlf., The Ghaznavids Their Empire in Afghanistan and Eastern Iran 944:1040, Edinburg 1963.; Aym mlf., The Later Ghaznavids: Splendour and Decay, Edinburg 1977.

${ }^{2}$ Bk. The Buwayhid Dynasty of Baghdad, Calcutta 1964; Ayrica bk., H. Busse, Chalif und Grosskōnig, Die Buyiden im Iraq (945-1055), Beirut 1965.

${ }^{3}$ Bk. A. Usta, Samaniler Devleti'nin Siyasî ve Kültürel Tarihi (943-1005), İstanbul 2003 (Basılmamış Doktora Tezi).

4 Bk. Tarih-i Sistan, nşr. Melik üş-Şüera Bahar, Tahran hş. 1314, s.309; C.E. Bosworth, The History of Saffarid of Sistan and the Maliks of Nimruz, Costa Mesa, California and New York, 1994, s. 282, 348-349. 
nadıkları görülüyor. Bu durumda Hintliler acaba hangi tarihten itibaren Gazneli ordusunda görev almaya bașlamıșlardır?

Simcurîler Horasan'a hâkim olmak ve Samanîler'in yerine geçmek isteyen bir Türk âilesidir. Bu âileden Ebû Ali Simcurî, Sebüktegin zamanında Samanîler tarafindan Horasan ordu komutanlığına (Sipehsâlâr-1 Horasan) tayin edilen (994) Sebüktegin' in oğlu Mahmûd'u Nişabur civarında mağlup etmiști (995). Ebû Ali'nin daha sonra özür dileme gayretlerine rağmen, Sebüktegin, oğlu Mahmûd'un intikamını almak için, etrafa mektuplar yazarak asker göndermelerini istedi. Sebüktegin bu sırada Hintliler'den ve Türk Halaçlar'dan da asker toplamıșt. Neticede 22 Temmuz 995 tarihinde Tus civarındaki savașta Sebüktegin, Ebû Ali Simcurî ve ordusunu mağlup etti ${ }^{5}$. Böylece Gazneliler ordusunda insan gücü olarak Hintliler ilk kez muhtemelen 995 tarihinde görev almıș görünüyorlar.

Sultan Mahmûd zamanında (998-1030) da Hintliler, Gazneli ordusunda yer almıșlard $1^{6}$. Bu sırada Hintliler'in Gazneli ordusunda yer almalarında dinin bir engel teșkil etmediği görülüyor. Nitekim Sultan Mahmûd 21 Aralık 1002'de Sîstan'a hâkim olduktan sonra orada bir miktar asker birakarak Gazne'ye döndü. Ancak bir süre sonra Sîstanlılar, Ebû Bekr Abdullah idaresinde Gazneliler'e karşı ayaklandılar ve duruma hâkim olarak onun adına hutbe okuttular. Öte yandan sultanın Sîstan'da bıraktığı üç bin kișilik Gazneli ordusunun çoğu Hintliler'den oluşmakta idi. Sisstanlılar bu Hintliler (Hinduvan-ı kâfir)den çoğunu öldürdüler ${ }^{7}$. Tarih-i Sîstan'da Hintliler'e âit Sistan ile ilgili bilgiler bu kadardır. Sultan Mahmûd daha sonra 10-11 Ekim 1103'de Kurban Bayramı'nda Halefâbâd'daki Erk kalesine hâkim olarak asîlerin isyanımı bastırdığında; Gazneli askerlerin pazarları ve sarayları yaktıkları, Cuma câmiini yağmaladıkları ve kilisede Hıristiyanları öldürdükleri sırada Hintliler'in Gazneli ordusunda yer aldığı hususunda Tarih-i Sîstan' da ${ }^{8}$ bir bilgi bulunmuyor. Ancak Prof. Bosworth"' un bu orduda Kâfir Hintliler'in de yer aldığı hususunda verdiği bilgi, kanaatimce bir yorumdan ibarettir.

" Bk. Hace Ebu'l-Fazl Muhammed b. Huseyn Beyhakî Debir, Tarih-i Beyhakî, nşr. Dr. Gani ve Feyyaz, Tahran hș. 1324, s.206; Krş. E. Merçil, "Simcurîler IV", Belleten, sayı: 195. Ankara 1986, s.559-561.

${ }^{6}$ Bk. Nizâmül-Mülk, Siyaset-Nâme, Haz. M.A. Kōymen, Ankara 1999. Trk. Trc., s.72.

${ }^{7}$ Bk. Tarih-i Sistan, s. 355.

${ }^{8}$ Bk. S.357.

${ }^{9}$ Bk. Bosworth, "Military Organisation", s.55; Aynu mlf., The Ghaznavids, s.110. 
Karahanlılar'm da zaman zaman Horasan'ı ele geçirmek istediklerini görüyoruz. Nasr b. Ali Karahanlılar'dan biri idi ve Hoten hâkimi Yusuf Kadır Han'dan yardım istedi Tahminen kırk-ellibin kişi civarında bulunan birleșik Karahanlı kuvvetleri Sultan Mahmûd'un "Oğuz Türkleri, Halaçlar, Hintliler, Afganlılar, Gazne Türkleri ve Kürdler"den oluşan ordusuyla Belh'e 20 km. mesafede karşılaștı (5 Ocak 1008). Hintliler' in de yer aldığı Gazneli ordusu, fillerin de desteğiyle, Karahanlı kuvvetlerini mağlup etti. Bu savașta Hintliler ile Kürdler Gazne ordusunun merkezinde yer almıșlardı ${ }^{10}$.

Gazneli ordusunda hizmet eden Hintliler'in de, öteki gruplar (Deylemliler, Araplar ve Kürdler) gibi, Sipehsâlâr-ı Hinduyân denilen kendi komutanları vardı, onların karargâhları Gazne'de idi ${ }^{11}$. Ayrıca Hintliler gulam olarak yetiștirilerek Gazneli ordusunda hizmet etmekte idiler. Ancak burada belirtmemiz gereken bir husus gulâmın (Bk. E. Merçil, Gulam mad., $D \dot{I} A)$ İngilizce karșllığı olarak verilen slave kelimesinin bu terimi tam ifade edemediğidir. Çünkü slave'in karşılığı (köle, esir) efendisinin kayıtsız șartsız her türlü hizmetini yapan șeklinde ifade edilebilir. Halbuki gulâm, bir eğitim gördükten sonra hizmet ettiği kariyer içinde yükselebilir, hatta devlet dahi kurabilirdi, söz gelişi Gazneliler'in kurucusu Alptegin ile hanedanın kurucusu Sebüktegin gibi. Hintliler'e örnek olarak da Mes'ûd devrindeki olaylarda yer alan Tilek'i gösterebiliriz. Hintli gulâmlar ve askerler için devamlı bir kaynak tabiî ki, Hindistan'a yapılan seferler idi. Askerler bu seferler sonucu ele geçirilen esirler arasından seçiliyordu. Gazneli Mahmûd, Hindistan'a yaptğı ikinci seferinde Vayhand (Vayhin) Racası Caypal'ı mağlup etmiști (Kasım 1001). İbn el-Esîr'in ${ }^{12}$ verdiği sayıya inanabilirsek bu savaș sonrası Müslümanların eline ganimet olarak 500.000 esir geçmiști. Bu sayının çok abartulı olduğu kesindir. Yine Sultan Mahmûd H. 409/M. 1018'deki Kanavc seferinden 53.000 esir, 350 fil ganimet ile Gazne'ye dönmüștü ${ }^{13}$. Bu sefer so-

${ }^{10}$ Bk. Ebu'l-Șeref Nasıh b. Zafer Curfâdakanî, Tercümey-i Târîh-i Yeminî, nşr. Dr. Ca'fer Și'ar, Tahran hș. 1345, s.285-286; İbn el-Esîr, el-Kâmil Fi't-Târih, Beyrut neşri, 1979, cilt 9, s. 191/Trk. Trc., A. Özaydın, İslâm Tarihi el-Kâmil Fi't-Târîh Tercümesi, İstanbul 1987, IX, s.157; Raşid Al-Din Fazlallah, Cami' Al-Tavarih, II cild 4. cüz, nșr. A. Ateş. Ankara 1957, s.152; Bosworth, "Military Organisation", s. 52, 54; E. Merçil, Gazneliler Devleti Tarihi, Ankara 1989, s. $32-33$.

${ }^{11}$ Bk. Gerdizi, Zeyn el-Ahbâr, nşr. Abd el-Hayy Habibî, hṣ. 1347, s.195, 200; Beyhakî, s.497; M. Nazım, The Life and Times of Sultan Mahmud of Ghazna, London, 1931, s.140, not 7 ve 163; Bosworth, "Military Organisation", s.54.

${ }^{12}$ Bk. el-Kâmil, IX, s. 169-170/Trk. Trc., IX, s. 140.

${ }^{13}$ Bk. Gerdizî, s.184; Bosworth, aynı eser, s.45. 
nucu elde edilen esirlerin bir tanesi 2 ila 10 dirheme satulmışu ${ }^{14}$. Hintliler'in bir kısmı da Hindistan'da mevcut Kast sistemi nedeniyle Müslüman olarak Gazneli ordusuna kathliyorlard.

Sultan Mahmûd, Kanavc seferinden sonra Kalincâr Racası Ganda üzerine yürümeye karar verdi. $O$, Hindistan'a yapacağı onüçüncü sefer için (Ekim 1019), büyük bir ordu tertipledi. Bu ordu çeşitli milletlerden; Türk, Arap, Kürd, Deylem, İranlı ve Hintliler'den oluşuyordu ${ }^{15}$. Bu durumda Hindistan'a yapılacak seferlerde artuk Hintliler'in de yer aldığı ve onlara orduda rahatlıkla güvenilebileceği anlașillyyor.

Sultan Mahmûd'un ölümünden sonra iki oğlu Mes'ud ve Muhammed arasındaki taht kavgasında Hintliler'in de yer aldığı görüyoruz. Bu mücadelede esnasinda tahta oturan Muhammed'in aldığı bütün tedbirlere rağmen, dağılma yolunda ilk çatırdayan onun tarafı olmuştu. Birkaç kumandan ve saray gulâmlarından bir grup, başlarında Emîr Ayaz ve Ali Dâye olduğu hâlde batıda bulunan Mes'ûd'un yanına gitmek için Gazne'den kaçmışlardı. Bu haber Sultan Muhammed'e ulaştı̆ı zaman, Hintliler'in sipehsâlârı Suvendhray'ı bir grup atlı ile kaçanların peşinden gönderdi. Suvendhray bu kaçanlara yetişerek onlarla savaştı. Bu mücadelede Hintliler'den bir çok kişi ve Suvendhray öldürüldü. Öte yandan saray gulâmlarından (gulamân-ı saray) da bir çok kişi öldürülmüştü ${ }^{16}$. Bu olayda Türkler'den çok Hintliler'in Muhammed'e sadık oldukları anlaşılıyor.

Daha sonra bütün ordu komutanları ve büyükleri Teginâbâd denilen yerde bir araya toplanarak Muhammed'i tahttan indirdiler ve Mes'ûd'a tâbi oldular (4 Ekim 1030). Öte yandan haberciler 11 Ekim 1030 tarihinde Herat' ta bulunan Mes'ûd'un huzuruna gelerek "sultan" olduğunu bildirdiler. Sultan Mes'ûd bu olaydan sonra Teginâbâd'da bulunan Hâcib-i Buzurg Ali Karib'e bir mektup yazarak yanına çağırdı. Ertesi gün Ali Karib öteki askerlere Mes'ûd'dan gelen emir mucibince Herat'a gitmelerini söyledi. Fakat o Hint ordusunun (Leşker-i Hind) Teginâbâd'da kalmasını ve onların kendisiyle birlikte gideceğini belirtti. Böylece Ali Karib de Hintliler'e öteki askerlerden daha fazla güveniyordu. Ali Karib'in daha sonra filler, hazine ve Hint ordu-

${ }^{14}$ Bk. Curfadakanî, s.386; Raşid al-Din, s.208; İbn el-Esîr (el-Kâmil, IX, s.267-268/Trk. Trc., IX, s.210)' 'e göre, bir esir on dirheme satulyyordu.

${ }^{15}$ Bk. Muhammed b. Ali b. Muhammed Şebânkareî, Mecma'el-Ensâb, Tahran hş. 1363, s.54; Ayrıca ayn müellif mahallî olarak Kabilî ve Maveraünnehirlileri de zikrediyor.

${ }^{16}$ Bk. Gerdizî, s.195; Bosworth, "Military Organisation", s.55. 
suyla İsfizar'a ulaştığı haberi, Mes'ûd taraftarlarınca sevinçle karșılandı. Çünkü onun hiçbir şekilde Herat'a geleceğine inanmıyorlard $1^{17}$. Ali Karib, 2 Kasım 1030 'da Herat'a ulaşt ve ertesi gün sultanın huzuruna çıktı. Mes'ûd onu ve kardeşini tutuklatu, sonra da öldürterek servetine el koydu. Ali Karib' in öldürülmesinin sebebi, saltanat mücadelesine karışması ve Muhammed'i tahta geçirmesi idi.

Sultanın bu davranışı kendisine karşı ilk huzursuzluk belirtilerinin ortaya çıkmasına sebep oldu. "Kavm-i Mahmûdî" veya "Mahmûdiyan" denilen yani eskiden Mahmud'a hizmet eden devlet büyükleri Mes'ûd'un intikam duygusuyla harekete geçmesinden korkuya kapılmışlardı. Nitekim bu korkunun yersiz olmadığı biraz sonra ortaya çıktı. Mes'ûd önce Türk komutanlara karşı harekete geçti ve yanına çağırdığı eski Hindistan orduları komutanı Eryaruk'u tutuklattı. Eryaruk'un tutuklanması esnasında Hintli nakibler de 300 Hintli ile yer almıștı. Bu olay Eryaruk'un samimi arkadașı ve Mes'ûd'un tahta geçmesinde yardımcı olanlardan Asıgtegîn Gazî'nin sultanın yanından kaçmasına sebep oldu. Asıgtegîn bu sırada Karahanlı ülkesine, sonra da Harezmşâh Altuntaş'in yanına gitmek istedi ise de bunda bașarıh olamayarak Gazneli askerler tarafından yakalandı. Sultan Mes'ûd onun Gazne kalesinde hapsedilmesini istedi. Bu sırada Asıgtegîn'in yanına ona hizmet etmek ve lüzumlu eşyasını geri getirmek için üç Hintli gulâm satın alınmasını, Gazne kalesine götürmek üzere de 300 Hintli atlı ile 200 Hintli piyadenin görevlendirilmesini emretti. Burada ve buna benzer olaylarda Hintliler'in tercih edilmesinin sebebi, Türk askerlerin urkdaşlarına sempati göstermesini ve onlar lehinde harekete geçmesini engellemekti ${ }^{18}$.

Mes'ûd'un intikam aldığı kișilerden birisi de amcası Yusuf idi. Sultan daha babasının sağlığında kızını vermediği için amcasına kırgındı. Ayrıca Yusuf'un Muhammed'i desteklemesi ve onun ordu komutanı olması bu kırgınlığı daha da arturmıştı. Öte yandan Yusuf'un Karahanlılar ile mektuplaşması bardağı taşıran son damla olmuștu. Sonuçta Yusuf da tutuk-

${ }^{17}$ Bk. Beyhakî, s.52, 56. Hacib Ali Karib, Herat'a gelmeden önce orada olacakları tahmin etmis gibidir, ancak hayli iddialı konuşarak isterse elinde bulunan hazine, filler ve Hintliler'den oluşan ordu ile Bağdat'a kadar olan yerleri zapt etmesinin mümkün olduğunu, fakat kazaya rıza göstereceğini ifade etmiștir, bk. Aym eser, s.53-54.

${ }^{18}$ Bk. Beyhakî, s.228, 237; Krș. Bosworth, "Military Organisation", s.55; Aym mlf, The Ghaznavids, s.110. 
lanmıştı. O, bir kaleye üç Hintli komutan, üç nakib ve tam teçhizath 500 Hintli ath ve 300 seçkin yaya asker ile gönderilmiști $(422 / 1031)^{19}$.

Gazneliler, Kirman bölgesine Sultan Mes'ud devrinde hâkim olmușlardır. Kirman'dan gelen casuslar sultana da bölgenin karıșıklık içinde olduğunu, buranın hâkimi Büveyhîler'dan Ebû Kalicâr'ın akrabaları ile uğraştığından düzen ve adaleti sağlayamadığını bildirdiler. Sultan Mes'ûd hâkimiyeti altundaki Sîstan ve Rey bölgelerine komşu olan Kirman'1 mevkiinin öneminden dolayı zapt etmek istiyordu. Bu bakımdan Kirman üzerine Ahmed b. Ali Nuștegîn idaresinde gönderilen Gazneli ordusunda 2.000 Hintli, 1.000 Türk, 1.000 Kürd ve Arap olmak üzere 4.000 atlı ile her çeşitten 500 piyade bulunmaktaydı. Bu durum Gazneli Devleti'nin ordusunda çeşitli milletlerden asker bulunduğu konusunda iyi bir örnek teșkil etmektedir. Gazneli ordusu 1-12 Cumada I. 422/26 Nisan-7 Mayıs 103120 tarihinde harekete geçti ve Deylemlileri mağlup ederek dört ay içinde Kirman'a hâkim oldu.

Daha sonra Ahmed b. Ali Nuștegîn, Kirman'da asker üzerinde otoritesini tam olarak sağlayamamıs görünüyor. Bu sebeple Gazneli askerleri de Kirman'da tecavüz ve hırsızlıklara başladılar. Kirman halkı bu duruma tahammül edemez oldu ve Büveyhîler'den yardım istediler. Bir Büveyhî ordusu Kirman'a gelerek Gazneli kuvvetleri ile karșılaștı. Büyük bir savaş neticesinde Ahmed b. Ali Nuştegîn'in bütün gayretlerine rağmen, Hintliler'in mücadelede zayıf kalmaları, diğerlerini de ümitsizliğe düșürdü ve Gazneliler'in mağlubiyetine sebep oldu. Hintliler, Sîstan yolu ile Gazne'ye kaçtılar. Sultan Mes'ûd, Kirman mağlubiyetine sebep olan Hintliler'e çok kızdı. Onların ileri gelenlerinden altı tanesi kendilerine ketare $^{21}$ vurdular ve kanlarmı akıttılar. Sultan Mes'ûd "bu ketarenin Kirman'da vurulması gerekiyordu" dedi. Ancak sonradan Hintliler'in sayılarının az olduğu, ikmal yollarımın uzak bulunduğu șeklindeki mazeretlerini uygun görerek onları affetti ${ }^{22}$.

Sultan Mes'ûd devrinin önemli olaylarından biri de Hindistan ordusu komutanı (Salar-ı Hinduvân) Ahmed Yınaltegîn'in isyanı idi. Bu isyan ile il-

${ }^{19 .}$ Bk. Beyhakî, s.251-252: Bosworth, aym eserler, ayn yerler.

${ }^{20}$ Bk. Bosworth. (Military Organisation), bu olayn tarihini 425/1043 olarak vermekle yanılgıva düșmekte, ayrıca Kirman konusunda da az bilgi vermektedir.

${ }_{21}$ Bk. Ok, muzrak, kısa kulıç, Steingass, Persian-English Dictionary, s.1014.

${ }^{22}$ Bk. Beyhakî, s.430-432. Krş. E.Merçil, "Gazneliler'in Kirman Hâkimiyeti 1030-1034". Tarih Dergisi, say1: 24, Istanbul 1970, s.40-43. 
gili olarak yapılan "meșveret meclisi”nde Tilek-i Hindu ${ }^{23}$ söz alarak, “... Ben zaten Hindistanlıyım (orada) hava çok sıcaktır, o iklimde daha iyi sefer yapabilirim, eğer münasip görürseniz bu hizmeti benden esirgemeyin" dedi. Sonuçta Hindistan'a Tilek'in gönderilmesi kararlaştırıldı. Sultan onu görevlendirdikten sonra kendisine kös, alem (bayrak) ve muhteșem bir hil'at verilmesini emretti. Sipehsâlâr-ı Hinduvân Tilek hazırlıklarını yaptıktan sonra, sefere çıkanların âdeti üzere, Hintliler'den olușan mükemmel silâhlı atlı ve yaya ordusuyla sultanın önünden geçerek Hindistan'a hareket etti. Ahmed Ynaltegîn bu durumu öğrendiğinde açıkça isyan etti ve etrafına topladığı kuvvetlerle harekete geçti. Tilek'in âsilere sert davranması, yakaladıklarının sağ ellerini kestirmesi sonuç almasına imkân sağladı. İki taraf arasındaki savaşta Ahmed mağlup oldu, yanındaki Türkmenler ise ondan ayrılarak aman dilediler. Tilek onlara aman verdi. Öte yandan Ahmed yakın adamları ve 300 ath ile kaçmaya çalıștı. Ancak Tilek'in Catlar'a mektup yazarak yakalanması için para va'ad etmesi, Ahmed'in sonu oldu. Catlar onu yakalayarak öldürdüler ve oğlunu da esir ettiler. Onun kesik başı ve tutsak düşen oğlu Tilek'in yanına gönderildi. Sultan Mes'ûd, Tilek'in bu başarısına sevindi ve ondan Ahmed'in kesik başı ve oğlu ile huzuruna gelmesini istedi $\left(\right.$ Ekim 1034) ${ }^{24}$.

Bir süre sonra Tilek, Merv er-Rûd'da Sultan Mes'ûd'u karşılayarak saygılarını sundu. Tilek'in idaresinde tam teçhizath bir ordu ile komutanlar (mukaddemler) vardı. Eğer Beyhakî (s.494) isimleri karışturmadıysa, Timek Hindu da Tilek ile beraberdi. Ayrıca Tilek adında başka bir Hintli de onların yanında idi. Sultan, Tilek'e Ahmed Ynaltegîn'in isyanını bastırdığı için iltifatlarda bulundu ve Hintliler'in ileri gelenlerini yüksek bir yere oturttu. Ath ve yaya birliklerden oluşan Hintli ordusuna bunların önünden geçit resmi yapturdı. Beyhakî’ye göre (s. 494), "bu mükemmel bir ordu" idi. Bu sırada Hintli prenslerden haraca karșlık alınan ve bu orduda bulunan 55 fil de sultanın önünden geçirildi. Mes'ûd da bu Hintliler'den oluşan orduyu beğenmişti (Muhtemelen 426 sonu/1035 sonu) ${ }^{25}$. Daha sonra Tilek'e Hintli-

${ }^{23}$ Bir hacamatçının oğlu olan Tilek'in Sultan Mahmûd döneminden itibaren Gazneli Devleti'nde kariyerinin nasıl yj̈ıkseldiği hakkında bilgi için bk. Beyhakî, s.406-409; Gerdizî (s.200), onu Tilek b. Cehlen ( حهل ) olarak zikrediyor.

24 Bk. Beyhakî, s.404-406, 409, 423, 433-434; Gerdizî (s.200)'ye göre Ahmed Yınaltegin Sind nehrini geçmek isterken boğulmuştur.

25 Bk. Beyhakî, s.494; Bosworth, "Military Organisation", s.76; Aynı mlf, The Ghaznavids, s.101. 
ler'in komutanlığına (Salariy-i Hinduvân) mahsus olan bir hil'at verildi. Tilek bu hil'ati giydikten sonra sultanın huzuruna çıkarak saygılarımı sundu. Mes'ûd, henüz Tilek huzurunda iken hazinedânı çağırarak, mücevher ile süslü bir gerdanlığı (tavk) getirmesini emretti. Sultan bu gerdanlığı ayağa kalkarak kendi eliyle Tilek'in boynuna taktı ve Ahmed Yinaltegîn isyanmın bastırılmasında gösterdiği hizmetlerden dolayı son derece iltifatlarda bulundu (11 Safer 427/15 Aralık 1035) ${ }^{26}$. Bu durum Gazneli Devleti'nde milliyeti ne olursa olsun başarıh hizmetlerde bulunan şahısların mükâfatlandırıldığını ve kariyerinin üst noktasına kadar çıkabileceğini göstermesi açısından önemlidir.

Hârezm hâkimi Harun b. Altuntaş'ta da 1034 yılı ilkbaharında itaatsizlik ișaretleri görülmeye başladı. İsyan için görünüşte sebep, onun Sultan Mes'ûd'un sarayında rehine olarak bulunan kardeșinin ölümü idi. İsyanın hakikî sebebi ise, Horasan'da Türkmenler'in çıkardığı karışıklıklardan istifadeyle istiklâlini ilân etmek istemesiydi. Harun, Gazne'ye giden yolları da tutmuştu. Bu sırada Hârezm'den Gazne'ye bir seyyah geldi (10 Ramazan 425/29 Temmuz 1034) ve küçük bir kağıt getirdi. Bu kağıdı Gazneliler'in Hârezm'deki sahib-i beridi göndermiști. Ayrıca seyyah, sahib-i beridin bu bölge hakkında söylediklerini Gazneli ilgililere nakletti. Buna göre "Harezm" de bulunan Hâcib Beytegîn, Aytegîn Şarabdâr, Kalbak (قلباق ), Hintliler ve Sultan Mahmûd'un birçok komutanı, bu harekâtın aleyhindedirler. Fakat onların ellerinde ne var ki, bize yardım etsinler?" ${ }^{27}$. Bu ifadeden anlașıldığına göre, Gazneli ordusunda yer alan Hintliler eyaletlere de gönderilmekte ve Hârezm bölgesinde de bir miktar Hintli asker bulunmaktadır. Ancak onlar ve öteki Türk komutanlar bu isyanı bastıracak kadar kuvvetli değildirler.

Öte yandan Selçuklular da bağımsızlıklarımı elde etmek için harekete geçmişlerdi. Sultan onlara karşı Hâcib Beytoğdı idaresinde bir ordu gönderdi. Bu ordu her milletten 15.000 ath ile 2.000 saray gulâmmndan oluşmaktaydı (1035) ${ }^{28}$. Beyhakî'nin her cinsten (yani milletten) şeklindeki ifadesinden Selçuklular ile yapılan Nesa Savaşı'nda Gazneli ordusunda Hintliler'inde yer aldığı anlaşılmaktadır. Nitekim Gerdizî (s.99) daha açık bir

\footnotetext{
${ }^{26}$ Bk. Beyhakî, s.487.

${ }^{27}$ Bk. Aym eser, s. 422.

${ }^{28} \mathrm{Bk}$. Ayn eser, s. 481 .
} 
ifade kullanarak bu ordunun, "Hint, Kürd, Arap ve Türk"ten oluștuğunu belirtmektedir.

Sultan Mes'ûd'un zaman zaman Karahanlılar ile de başı derttedir. Böritegîn İbrahim b. Nasr, bir Türk kabilesi olan Kumeciler'in yanına kaçmış ve etrafına 3.000 kadar ath toplayarak Gazneli toprakları üzerindeki halka zarar vermeye başlamıștu. Sultan Mes'ûd bu olaydan sonra bazı tedbirler aldı ve Hâcib Sübașı'dan Derrey-i Gez'e gitmesini istedi. Bu sırada Hâcib Sübaşı ile beraber kendi köleleri ve askerlerinden başka 2.000 Türk ve Hintli ath bulunacaktı (Rebi I. Sonu 430/Aralık 1038) ${ }^{29}$. Sultan Mes'ûd daha sonra kıș şartlarına rağmen Böritegîn üzerine sefere çıkmaya karar verdi. Ancak Çağrı Bey'in Ceyhun kenarına ulaşarak bu nehir üzerindeki köprüyü yıkacağı şayiası, Mes'ûd'un Böritegîn'e karşı tertiplediği seferden vazgeçmesine neden oldu. Gazneli sultanı Belh'de iken, on Türkmen atlısı sultanın bu şehirde konakladığı bahçenin yanına gelerek dört Hintli piyadeyi öldürmüșler ve Mes'ûd'a âit bir fili de çalıp götürmüșlerdi. Mes'ûd bu olaydan sonra fil bakıcılarına ağır hakaretlerde bulundu, ihmali görülen Hintli fil bakıcılarının birkaç tanesinin dövülmesi ve filin bedeli olarak onlardan 100.000 dirhem alınmasını emretti. Bu olaylardan anlașıldığına göre, Sultan Mes'ud devrinde Hintliler ordunun her kademesinde görev yapmaktaydılar ${ }^{30}$.

Sultan Mes'ûd Gazneli topraklarını devamlı akınlarla rahatsız eden Selçuklular'a karşı harekete geçerek 9 Kasım 1039'da Herat'tan ayrılarak Buşenc'e doğru ilerledi ve şehrin sahrasında ordusunu düzene soktu. Bu orduda ath ve yaya askerlerden oluşan birçok Hintli vardı. Sultan bunları meşhur komutanların maiyyetine vererek ordunun merkezine, sağ ve sol kanatlar ile artçıların arasına dağıtt ${ }^{31}$.

Hintliler, Selçuklular ile Gazneliler arasında yapılan meşhur Dandanakan Savașı (22-24 Mayıs 1040)'nda da yer aldılar. Bu savaş sırasında Sultan Mes' ûd Gazneli ordusunda bulunan "Hintliler' in bir is görmediklerinden ve öteki askerlerin de maneviyatlarımı kırmalarından" şikâyetçi oldu. Ayrıca vezir de, "Hintliler'in komutanlarını ikaz etmek lâzımdır" demiști. Daha sonra sultan tarafından Hintliler çağrıldı ve ikaz edildi. Ancak onların komutanları

\footnotetext{
${ }^{20)} \mathrm{Bk}$. Aynu eser, s. 565.

${ }^{30}$ Bk. Aynu eser, s. 567

${ }^{31}$ Bk. Aym eser, s. 603.
} 
dà, "Biz sultanın önüne gidip aç olduğumuzu söylemekten sıkılıyor ve utanıyoruz. Bizim askerlerimiz açtur, atlar zayıflamıștır. Dört günden beri bizden hiç kimse arpa ve un yüzü görmemiştir ${ }^{32}$. Böyle olmakla beraber biz ölünceye kadar hizmette kusur etmeyiz. Bu gece bütün adamlarımıza söylenmesi gerekli sözleri söylemek lâzımdır" diyerek dönüp birliklerinin yanına gittiler. Böylece Hintli komutanlar güç şartlar altunda savaştıklarını ifade ederek sultana mazeretlerini bildirmiș oldular. Ancak daha sonra Selçuklular'ın üstünlüğü karşısında Hintliler de bozguna uğrayarak savaș meydanından kaçmışlardı. Onların yapacak fazla bir şeyleri yoktu. Çünkü Kürd ve Araplar çoktan kaçmışlardı. Böylece Gazneli ordusu Dandanakan Savaşı'nda Selçuklular karșısında tam bir mağlubiyete uğramıșt ${ }^{33}$.

Sultan Mes'ûd, özellikle Dandanakan mağlubiyetinden sonra, Hindistan'a gitmeyi aklına koymuștu. Bu maksatla Gazne'de toplanan hazineleri de götürmek istedi. Devleti ileri gelenleri bu fikre karșı çıkular. Ayrıca Gazneli veziri Ahmed b. Abdüssamed sultana yazdığı mektupta, “... Şu iyi bilinsin ki, eğer sultan bütün haremi ve hazineleriyle Hindistan'a giderse bu haber dünyaya yayılır... düșmanların bize karşı tamahı ziyadeleşir. Bundan başka Hintliler'in nesine güvenip de haremler ve hazineler oraya götürmeye teșebbüs ediliyor. Hintliler'e ve gulâmlara ne dereceye kadar güvenilebilir." şeklinde ifadelerle Mes'ûd'u uyarmaya çalıștı ise de başarılı olamadı ${ }^{34}$. Nitekim Sultan Mes'ûd, Sind nehrini geçtikten sonra Mârikale denilen yerde hazineye göz koymuș olan Türk ve Hintli gulâmların ayaklanmasıyla karș̣lașu (bendegân-1 Türk ve Hind bervey huruc kerdend). Bunlar hazineyi yağmalayıp paylarını aldıktan başka, ordunun öteki kısmını da isyana teşvik ettiler $^{35}$. Bu suretle devlet ileri gelenlerinin ve vezirin daha önce söyledikleri üzere, sultanın hazineyi beraberine almasıyla doğacak tehlike gerçekleşmiş oldu. İsyan eden Gazneli ordusu Mes'ûd'un daha önce köredilen kardeși Muhammed'in etrafinda toplanarak ikinci kez sultan ilân ettiler (21 Aralık 1040) ve Mes'ûd'u da öldürdüler.

32 Nitekim daha önce Gazneli veziri komutanlardan Altuntaş ile yapuğı görüşmede. "Hintliler'in yaya ve aç olduğunu" ifade etmişti, bk. Beyhakî, s. 614 .

${ }^{33}$ Bk. Beyhakî, s. 621-622, 624.

${ }^{34}$ Bk. Aynı eser, s. 662; Bosworth, The Later Ghaznavids, s. 15-16.

${ }^{35}$ Bk. Kadı Minhac-ı Sirâc Cüzcanî, Tabakat-ı Nâsırî, nșr. Abd el-Hayy Habibî, Quetta 1949, I. S.276; Öteki kaynaklar söz gelişi Sadr el-Dîn el-Hüseynî (Ahbâr üd-Devlet is-Selçukiyye, nşr. Muhammed İkbal, Lahor 1933, s. 14/Trk. Trc., N. Lügal, Ankara 1943, s. 10) ve İbn el-Esîr (IX, s. 485/Trk. Trc., IX, s. 370) gulâmlanın hazineye göz dikip yağmaladıklarımı zikrediyorlar. 
Bundan sonraki dönemlerde kaynaklar Gazneli ordusundaki Hintliler hakkında fazla bilgi vermiyor. Ancak zaman zaman Gazneli hanedan mensuplan kendi aralarındaki taht mücadelelerinde ve Gurlular'a karşı verdikleri savaşlarda Hindistan'a gittiler ve buradan kuvvet toplayarak geri döndüler. İște bu sırada Gazneliler, Hindistan'daki insan kaynağından asker olarak faydalanmıșlardır. Söz gelişi, Selçuklu Meliki Sencer, Behramşâh'a yardım için Gazne'ye bir sefer tertipledi ve 25 Şubat 1117 tarihinde bu șehre girerek Gazneliler tahtına oturdu. Sultan Arslanşâh ise saltanat mücadelesine devam edebilmek için Hindistan'a kaçmış ve oradaki valisi Muhammed-i Ebû Halim (veya b. Ali)'den yardım istemiști. O, Sencer'in Gazne'den ayrıldığını duyduğu zaman, Hindistan'da topladığı kuvvetler ile geri dönerek Behramşâh'a hücum etmişti ${ }^{3 i .}$.

Gurlular'dan Seyfeddîn Surî başkent Gazne'yi ele geçirdiği zaman (Eylül-Ekim 1148), Sultan Behramşâh, Hindistan'a çekilmiști. Gazneli sultanı daha sonra Hindistan orduları ve topladığı askerlerin yardımıla tekrar Gazne'ye sahip olmuştu ${ }^{37}$. Bu olaylar sırasında Gurlu Seyfeddîn Surî de öldürülmüsstü. Gurlular'dan Alaeddîn Huseyn intikam almak maksadıyla büyük bir ordu toplayarak Gazne'ye doğru harekete geçti. Sultan Behramşâh onun niyetini öğrendiği zaman Gazne, Hindistan ve Hintli vasal prenslerden büyük ordular topladı. Ancak bu bir fayda sağlamamıș, Alaeddîn Hüseyn, Sultan Behramşâh'ı mağlup ederek ele geçirdiği Gazne'yi yedi gün yedi gece ateșe vermiști $(1151)^{38}$. Sultan Sencer'in 1152 'de yapılan savaşta Gurlu Alaeddîn Huseyn'i mağlup ve esir etmesi, Behramșâh'a yeniden Gazne'ye sahip olma firsatum verdi. O, Hindistan'dan harekete geçerek tekrar Gazne'ye hâkim oldu (1152) ${ }^{3 !}$. Gazneli sultanı Hindistan'dan harekete geçtiğine göre, bu seferde de ordusunda Hintliler'den faydalanmış olmalıdır.

Sultan Behramșâh döneminde önemli olaylardan biri de Gazneliler'in Hindistan orduları komutanı Muhammed-i Ebû Halim ile oğlu Mu'tasım'ın isyanı idi. Bu asî komutanın ordusu rivayete göre 70.000 kişi idi ve Müslümanlar ile Hintliler'den olușuyordu. Bu olay bize Hindistan'daki Gaz-

${ }^{36}$ Bk. Ghulam Mustafa Khan, A History of Bahram Shah of Ghaznin, Lahore 1955, s. 22 ve 32; Bosworth, The Later Ghaznavids, s. 97.

${ }^{37}$ Bk. İbn el-Esîr, XI, s. 135, 164-165/Trk. Trc., XI s. 124, 145; Ghulam Khan, s. 49; Bosworth, The Later Ghaznavids, s. 114.

38 Ghulam Khan, s. 53-54 ve 59; M.A. Köymen, Büyük Selçuklu Imparatorluğu Tarihi, Ikinci Imparatorluk Deiri, Ankara 1984, s. 369-372; Bosworth, aym eser, s. 116.

${ }^{39}$ Bk, Ghulam Khan, s. 69; Bosworth, aym eser, s. 119. 
neli komutan (veya vali)ların ordularında da Hintliler'in yer aldığını gösteren örneklerden biridir ${ }^{10}$.

Gazneliler'in Hintliler'den yararlandıkları bir saha da orduda bulunan fillerin bakımı idi. Çünkü Gazneliler filleri kullanmayı Hindistan'dan öğrenmişlerdi. Bu hayvanların bakımıyla filban denilen Hintliler uğraşıyordu ${ }^{41}$.

Öte yandan bazı Hintliler'in komutan olarak Gazneliler Devleti'nde önemli görevler aldığını görüyoruz. Bunlardan tespit edebildiğimiz Arslan Hindu-beççe ${ }^{12}$, Sultan Mahmûd döneminde Kuhistan valisi tayin edilmişti. Bir kale komutan olan Cengi ${ }^{13}$ de Hintli idi. Suvendhray ${ }^{44}$, Sultan Muhammed'e sadık kalan ender komutanlardan biri idi ve bu uğurda hayatım kaybetmişti. Sanguy ${ }^{15}$ da muhtemelen Hintli komutanlardan biridir. Meşhur Tilek'in yanısıra, Beyhakî, isimleri karıştırmadıysa, daha önce geçtiği üzere, adașı başka bir Tilek ile Timek'i de burada zikdebiliriz. Sonuç olarak, Gazneliler tarih sahnesinden çekilene kadar, Hintliler de bu devletin ordusunda -bir-iki olay dışında- sadıkâne görev yapmışlar ve bunlardan bazıları kariyerlerinin en üst noktasına kadar yükselmişlerdir.

1" Bk. Bosworth, The Later Ghaznavids, s. 102; Ghulam Khan, s. 34.

$"$ Bk. Abbâs-1 Perviz, s. 371; Busse, Chalif und Grosskōnig, s. 346; Bosworth, "Military Organisation", s. 61 vd; Ayn mlf, The Ghaznavids, s. 115 vd.; Gazneli ordusundaki filler ve Hintli bakıcılar için kanaatimce ayrı bir araşturma gerekmektedir.

${ }^{12}$ Bk. Curfadakanî, Tercümey-i Tarih-i Yeminî, s. 243; Sadece Hindi-beççe için bk. Gerdizî, s. 175 .

${ }^{13}$ Bk. Gerdizî, s. 196 not 5; Beyhakî, s. 65. 83, 149; Raşid al-Din, Cami Al-Tararih. s. 202.

${ }^{41}$ Gerdizi, s. 195. Ayrıca isim için Bk. Beyhakî, s. 407.

${ }^{15}$ Bk. Bosworth, The Later Ghaznavids, s. 17. 